\title{
GILBERTO FREYRE: E O MITO SE FAZ HISTÓRIA
}

Celso Vianna Bezerra de Menezes

m um recente artigo publicado no caderno "Mais" da Folha de

São Paulo, o antropólogo Hermano Vianna desafia os leitores a encontrar, em qualquer das páginas de Casa Grande \& Senzala, a expressão mais discutida quando se fala de Gilberto Freyre: "democracia racial". Esta tal de "democracia racial" ganhou importância, tornou-se verdadeiramente um "mito" e acabou por obliterar todo o restante da vasta e importantíssima obra daquele que, deixando de lado preferências pessoais, deveria ser considerado, sem dúvida alguma, o maior antropólogo/sociólogo brasileiro. É bem verdade que Hermano Vianna propõe uma falsa questão, já que a simples ausência da expressão "democracia racial" de forma alguma invalida as críticas que são dirigidas a Gilberto Freyre, pois outras expressões aparecem no livro e acabam por levar à mesma imagem que se pretende negar. Em Casa Grande aparecem expressões como "paraíso tropical", "doçura das relações de senhores e escravos", "fusão harmoniosa de culturas" e outras tantas mais.

Entre defensores e críticos de Gilberto Freyre, notamos opiniões dicotômicas e maniqueístas que acabam por impedir uma leitura crítica e enriquecedora da obra freyriana e, em consequiência, da realidade brasileira. Desde os anos de minha graduação, quando passei vários dias lendo o Casa Grande com espanto e admiração, não deixo de ouvir as pessoas dizerem: "Ler Gilberto Freyre ? Não é ele que fala de 'democracia racial'?’. Desde aqueles anos, inúmeras gerações de alunos de Ciências Sociais terminaram seus cursos sem terem lido uma única linha escrita por Gilberto Freyre. É uma pena.

O objetivo deste trabalho é tentar situar a obra de Gilberto Freyre no contexto das discussões sobre esse tal de "brasileiro", este ser recém 
descoberto após o fim da escravidão. Até então, a sociedade brasileira resumia-se a um pequeno número de "senhores", um grupo numeroso de "homens livres", mas com pouca função nesta sociedade, e os negros escravizados desconsiderados como "gente", pelo menos como os "brancos" se consideravam. O país, portanto, resumia-se a uma pequena elite e seu destino.

Naquela época, três linhas de pensamento eram dominantes na discussão sobre as questões que envolviam as diferenças entre os homens. Essas diferenças eram explicadas essencialmente pela "diversidade racial". Uma primeira linha, a dos poligenistas, defendia que os homens teriam se originado de ancestrais diversos, o que explicaria a diferença das diversas "raças" então existentes, resultado direto da sua criação como espécies distintas. Louis Agassiz, um zoólogo suíço, era o mais importante representante deste pensamento que, através da coleta de evidências empíricas, portanto científicas, afirmava a superioridade da raça branca. As diferenças físicas, deste modo, davam provas das diferenças culturais e comprovavam também que a miscigenação conduzia a uma degeneração do homem, além de sua esterilidade. Lembremos que o termo "mulato", tanto no espanhol como no português, tem sua origem no termo "mula", animal híbrido e, por consequiência, estéril.

Uma segunda linha de pensamento denominada "escola histórica", representada principalmente por Arthur de Gobineau, que escreveu a obra Ensaio sobre a desigualdade das raças humanas, afirmava haver uma evidência histórica das diferenças físicas permanentes entre as raças humanas. Era evidente que havia um triunfo das raças criadoras, a anglo-saxônica sendo dentre todas a mais destacada. A raça era o fator determinante da história humana.

A terceira linha foi o "darwinismo social", com a proposição de que, na evolução das raças humanas para formas superiores de vida, assistiríamos à sobrevivência dos mais aptos, tal como a seleção natural de todas as outras espécies de animais. Justificava-se, assim, a dominação dos "brancos" e a sua sobrevivência em detrimento das outras raças. Saliente-se que o darwinismo acabou sendo incorporado até mesmo pelos poligenistas, em franco desafio à idéia monogenista inerente ao modelo explicativo de Darwin.

Abramos um parêntese para e lembremos que Euclides da Cunha, no seu Os Sertões, imbuído das idéias do determinismo biológico e também 
do geográfico (sintomaticamente seu livro foi dividido em três partes: a terra, o homem e a luta), descrevia o sertanejo como o "mulato degenerado do interior". Aliás, acredito que a beleza do livro de Euclides da Cunha está em grande parte numa ambiguiidade: ele chega a Canudos com esta visão dos sertanejos, mas, após as três vitórias que eles conseguem sobre o "grande exército brasileiro", que acabara de voltar vitorioso da Guerra do Paraguai, passa a considerar o sertanejo, "antes de tudo um forte".

No Brasil, os homens de ciência, embora incorporassem aquelas idéias racistas dominantes na Europa e Estados Unidos, procuravam adequá-las à realidade dos trópicos. Aqui, a presença de uma sociedade multirracial era por demais evidente para que pudesse ser desconsiderada. No dizer de Lilia Schwarcz (1996, p.172), de um lado, "era interessante referendar as posições dos cientistas europeus e americanos, porque significava transformar hierarquias sociais, políticas e econômicas em hierarquias naturalizadas. Responsabilizava-se a natureza pelo que cabia, exclusivamente, à sociedade. Por outro lado, porém, era muito mais complicado absorver o que diziam as teorias de fora com relação à mestiçagem. Segundo os modelos da época, pior do que as 'raças puras inferiores', eram as raças mestiças, já que da mistura de espécies muito diferentes só poderiam surgir produtos absolutamente degenerados. Portanto, vejam que os intelectuais brasileiros eram obrigados a lidar com uma parte da teoria e obliterar outra". O problema de difícil solução que se punha aos brasileiros era reconhecer que a miscigenação, extremada entre nós levaria ao fracasso da nação.

A tentativa de solucionar a presença do mestiço entre nós veio com a "teoria do branqueamento". Em 1911, o presidente Marechal Hermes da Fonseca nomeia João Batista Lacerda, um cientista de renome internacional, como representante do Brasil no Congresso Mundial das Raças, em Paris. Neste congresso, Lacerda expõe a teoria do branqueamento cujo objetivo era, de algum modo, mostrar a viabilidade do Brasil enquanto nação. Argumentava na sua exposição que a população brasileira estaria eliminada de seus traços negros, tanto cultural como físicos, ao fim de um século, três gerações segundo seus cálculos. (Será preciso avisar urgentemente a todos os brasileiros pois, segundo estes cálculos, nós só temos mais doze anos para ficarmos branquicelos). O branqueamento se daria por uma conjunção de fatores: por um lado, os negros, deixados à sua própria sorte, 
sucumbiriam; por outro lado, ele sugeria que, através de leis de proteção e garantias, os fizessem dispersar pelas áreas rurais do país, pois que os negros eram bons trabalhadores agrícolas. Já a população mestiça, que ele reconhecia não ser estéril, seria paulatinamente branqueada, pois a raça branca, mais forte, imporia a dominação de seus genes e, para isso, deveria contar com a ajuda dos migrantes brancos, sobretudo europeus. Tal "ajuda" vinha sendo incentivada por uma política deliberada do governo brasileiro no fomento à imigração.

Em suma, esta era uma discussão fundamental no país dos inícios do século XX. A questão racial torna-se fundamental entre nós após a abolição. A urbanização, aponta Celso Furtado (1984, p.44), torna a presença do "povo" visível para a elite do país. Discutir, portanto, se este era um país viável, passaria pela discussão de soluções para esta sociedade misturada, mas também, como vimos, "racista". Trata-se de um "racismo mestiço". Poderíamos até dizer, um "racismo mestiço envergonhado". Assim sendo, se quisermos analisar a obra de Gilberto Freyre, devemos pensá-la neste contexto social, político e científico.

Em 1917, com 17 anos, Gilberto Freyre termina seus estudos secundários e segue para os Estados Unidos para fazer os cursos superiores. Após o bacharelado em Baylor, ele vai para Columbia. Nesta universidade, tem por mestre Franz Boas, que era um geógrafo alemão que havia migrado e "se convertido" à antropologia. Foi um dos primeiros antropólogos a fazer "pesquisa de campo", sendo considerado o criador da "etnografia". Toda a sua obra foi uma tentativa de pensar a "diferença" entre os grupos humanos, que ele atribuía a fatores de ordem cultural e não racial. Tratava-se, portanto, de desmontar a noção de "raça". Ele procurou mostrar o absurdo que era a idéia de uma ligação entre traços físicos e traços mentais, implícita na noção de raça. A característica dos grupos humanos no plano físico é a sua plasticidade, sua instabilidade, sua "mestiçagem", logo era preciso abandonar o conceito de "raça" na explicação dos comportamentos humanos. Boas foi a pessoa que marcou de forma profunda toda a produção antropológica norte-americana e no resto do mundo, pois condenou veementemente a teoria evolucionista linear (a teoria dos três estágios: selvageria, barbárie, civilização) e defendeu o "particularismo histórico" ( a chamada Escola Cultural Americana), segundo o qual cada cultura 
segue os seus próprios caminhos em função dos diferentes fatos históricos que enfrentou. Uma abordagem "multilinear", portanto, e com uma concepção relativista que afirma a dignidade de cada cultura e exalta o respeito e a tolerância em relação a culturas diferentes.

A estada de Gilberto Freyre nos Estados Unidos, onde a realidade e as discussões sobre as raças seguia um caminho bastante distinto do caso brasileiro, e seu convívio com Boas e o culturalismo americano levaram-no a um análise radicalmente diferente daquelas então em voga no Brasil, embora não tenha conseguido desvencilhar-se de todo da preocupação com as raças (veja suas análises da relação entre alimentação e raça, na Introdução de Casa Grande e Senzala, que seguem as pegadas do seu mestre Boas). Sua preocupação primordial era, como aliás de toda a elite pensante brasileira, visualizar as possibilidades desta sociedade tropical miscigenada. Porém, ao contrário das análises e soluções apresentadas pelos "racistas brasileiros" que preconizavam uma eugenia da população, Freyre envereda por um caminho oposto, ou seja, ele abandona aquele "racismo envergonhado" e parte, dentro de uma visada culturalista, para a constatação e, depois, para a defesa da miscigenação à brasileira. Assim, para ele, a miscigenação deixa de ser um "problema" a ser resolvido e torna-se uma qualidade. Ele afirma:

E não sem certas vantagens: as de uma dualidade não de todo prejudicial à nossa cultura em formação, enriquecida de um lado pela espontaneidade, pelo frescor de imaginação e emoção do grande número e, de outro lado, pelo contato, através das elites, com a ciência, com a técnica e com o pensamento adiantado da Europa. Talvez em parte alguma se esteja verificando com igual liberalidade o encontro, a intercomunicação e até a fusão harmoniosa de tradições diversas, ou antes, antagônicas, de cultura, como no Brasil.[...] Mas não se pode acusar de rígido, nem de falta de mobilidade vertical o regime brasileiro, em vários sentidos sociais um dos mais democráticos, flexíveis e plásticos. (Freyre, 1980, p. 52)

É impossível não perceber, na análise de Gilberto Freyre a respeito do Brasil, uma caracterização quase que por oposição à realidade norteamericana, onde a coexistência entre brancos e negros se fez e se manteve rigidamente separada. Nessa citação, percebe-se um conceito central e 
recorrente em toda a obra de Freyre, como apontou Ricardo Benzaquem Araújo (1994, p. 18): a noção de "equilíbrio de antagonismos", que seria uma característica dos portugueses desde a sua convivência com os muçulmanos na Península Ibérica dominada, depois reconquistada. Ele enxerga esse equilíbrio na vida política (a tradição conservadora entre a Ordem e a Liberdade), nas relações raciais (onde os africanos aproximaram os extremos), na vida social e cultural etc. Freyre descreve os antagonismos e conflitos para então mostrar como eles são acomodados e têm suas durezas atenuadas:

O sistema casa-grande - senzala, que procuramos estudar em trabalho anterior, chegara a ser - em alguns pontos pelo menos - uma quase maravilha de acomodação: do escravo ao senhor, do preto ao branco, do filho ao pai, da mulher ao marido. Também uma quase maravilha de adaptação do homem, através da casa, ao meio físico, embora, neste particular, o sobrado e o mucambo talvez tenham superado o sistema inicial. (Freyre, 1985, p. XLI)

O equilíbrio dos antagônicos pode ser percebido no próprio título da principal obra de Gilberto Freyre, Casa Grande \& Senzala, onde o símbolo " \&" aparece no lugar do "e", que é uma conjunção aditiva, mas também adversativa. $O$ " $\&$ " de uso comum na linguagem jurídica remete à idéia de somatória, de união de interesses e esforços. "Pois dentro desse sistema muita comunicação houve entre casas-grandes e senzalas, entre sobrados e mucambos e não apenas separação ou diferenciação. Síntese e não apenas antítese. Complementação afetiva e não apenas diversificação economicamente antagônica" (Freyre, 1985, p. LXIX). Não à toa o antropólogo troca o "\&" pelo "e" quando em Sobrados e Mucambos vai descrever justamente o processo de decadência do sistema patriarcal brasileiro.

Assim sendo, acredito que seria muito mais enriquecedor enxergar o Gilberto Freyre dos "equilíbrios antagônicos" que, aliás, como ele faz questão de apontar, podem desandar em conflitos, do que permanecermos nesta eterna repetição do "mito da democracia racial". Parece, como afirma Lilia Schwarcz (1996, p. 177), que é uma atitude insensata nos atermos em criticar o mito da democracia racial, pois 
diferente da interpretação que vincula a noção de mito ao conceito de ideologia , no sentido de que ambos mascaram a realidade, melhor pensar com o estruturalismo e ver o que o mito revela, já que ele é uma linguagem que ilumina contradições. Questionemos, então, por que justamente Gilberto Freyre, o antropólogo que deslocou o eixo de discussão sobre o Brasil das "raças" para "cultura", tornou-se o responsável pelo "mito da democracia racial?" Por que a raça é uma questão tão fundamental entre nós ? Por que é que continuamos a definir este país pela raça ? Enfim, melhor seria pensar como e porque o mito se faz história, já que, "se o olho é o órgão da tradição", como nos diz Boas, talvez "sejamos mesmo míopes culturais", como nos alerta Lilia Schwarcz.

Por fim, gostaria de deixar assinalada uma contribuição extremamente importante deixada por Gilberto Freyre: trata-se de sua enorme inovação metodológica - lembremos que Casa Grande foi publicado pela primeira vez em 1933 -, quando passa a produzir uma antropologia em estreita combinação com a história. Portanto, há quase setenta anos atrás, Freyre produziu uma obra de "História Cultural", tão em moda nos dias atuais. Parece ter sido Fernand Braudel, o historiador francês, quem primeiro assinalou, na introdução à tradução italiana de Casa Grande, este caráter inovador da obra de Gilberto Freyre. Uma "história íntima", "do cotidiano", de "carne e osso" como, aliás, preconizava o antropólogo Bronislaw Malinowski na clássica Introdução de seu Argonautas do Pacífico Ocidental.

Dizia Gilberto Freyre para definir sua obra: esta "história íntima", este "romance", mas "romance verdadeiro", "romance" descoberto pelo observador, ao mesmo tempo intérprete e participante da história ou da atualidade estudada; e não inventado por ele" (Freyre, 1985, p. LXV)

\section{Referências Bibliográficas}

ARAÚJO, Ricardo Benzaquem. Guerra e Paz. Rio de Janeiro: Editora 34, 1994.

CUCHE, Denys. A noção de cultura nas ciências sociais. Bauru: EDUSC, 1999.

FREYRE, Gilberto. Casa Grande \& Senzala. Rio de Janeiro: Livraria José Olympio, 1980. 
Sobrados e Mucambos. Rio de Janeiro: José Olympio, 1985.

FURTADO, Celso. "Que somos ?" in Folha de São Paulo. São Paulo, 28/04/1984.

LARAIA, Roque de Barros. Cultura. Um conceito antropológico. Rio de Janeiro: Jorge Zahar Editor, 1986.

MONTES, Maria Lúcia. "Raça e Identidade: entre o espelho, a invenção e a ideologia" in Raça e Diversidade. Lilia M. Schwarcz e Renato da Silva Queiroz (orgs.). São Paulo: EDUSP, 1996.

SCHWARCZ, Lilia Moritz. O Espetáculo das Raças. São Paulo: Cia. das Letras, 1993. "As teorias raciais, uma construção histórica de finais do século XIX. O contexto brasileiro". in Raça e Diversidade. Lilia M. Schwarcz e Renato da Silva Queiroz (orgs.). São Paulo: EDUSP, 1996.

SKIDMORE, Thomas E. Preto no Branco. Rio de Janeiro: Paz e Terra, 1976.

\section{Resumo}

Este trabalho não pretende fazer uma defesa de Gilberto Freyre, mas, fugindo de certas leituras que nos parecem empobrecedoras da obra freyriana, situá-la no contexto das discussões sobre o Brasil, nas primeiras décadas do século XX. Para tanto, propomos um deslocamento no foco da leitura de Casa Grande \& Senzala: abandonar a noção de "democracia racial" para lançar mão de uma outra noção que nos parece central nesta obra, a de "equilíbrio de antagonismos". Julgamos que assim podemos nos aproximar da contribuição que este autor deu para o entendimento da realidade brasileira contemporânea.

Palavras-chave: raça; cultura; democracia racial; miscigenação.

\section{Abstract}

Instead of make a defense of Gilberto Freyre, this paper escaping from some readings that seem to impoverish the Freyre's work, intends to place it in the brazilian issues context during the beginning of the XX century. We propose to dislocate the reading focus of "Casa Grande \& Senzala, abandoning the "racial democracy" concept grasp of another idea, which seems to be fundamental to his thought, the "antagonism equilibrium". Maybe this new focus can let us closer to the Freyre's contribution to understand the contemporary brazilian reality.

Key-words: race; culture; racial democracy; miscegenation.

Celso Vianna Bezerra de Menezes é professor do Departamento de Ciências Sociais da UEL 